\title{
Polycyclic Aromatic Hydrocarbons in Water, Soils and Surface Sediments of the Msunduzi River
}

\author{
Alexis Munyengabe ${ }^{1^{*}}$, Allen Mambanda ${ }^{1}$ and Brenda Moodley ${ }^{2}$ \\ ${ }^{1}$ School of Chemistry and Physics, Pietermaritzburg Campus, 3209, University of Kwazulu-Natal, South Africa \\ ${ }^{2}$ School of Chemistry and Physics, Westville Campus, Durban 4000, University of Kwazulu-Natal, South Africa
}

"Corresponding author: Alexis Munyengabe, School of Chemistry and Physics, Pietermaritzburg Campus, 3209, University of Kwazulu-Natal, South Africa, Tel: +27629832402; E-mail: 212562429@stu.ukzn.ac.za

Received date: December 11, 2017; Accepted date: December 20, 2017; Published date: December 26, 2017

Copyright: (c) 2017 Munyengabe A, et al. This is an open-access article distributed under the terms of the Creative Commons Attribution License, which permits unrestricted use, distribution, and reproduction in any medium, provided the original author and source are credited.

\begin{abstract}
The concentration of seven Polycyclic Aromatic Hydrocarbons (PAHs) (namely Naphthalene, Acenaphthylene, Fluorene, Phenanthrene, Anthracene, Pyrene and Chrysene) were determined in 28 surface waters, 8 wastewaters, 26 soils and 26 surface sediments from the Msunduzi River, a major supply of portable water in KwaZulu-Natal (KZN) province, South Africa. Water samples were extracted using a conventional liquid-liquid extraction technique into Dichloromethane (DCM) while soils and surface sediments were extracted with an equal mixture of DCM and nhexane using the Soxhlet extraction technique. Purified extracts were analysed by Gas Chromatography-Mass Spectroscopy (GC-MS). Trace levels of PAHs were detected in some water, river bank soils and surface sediments. The concentration of PAHs was found to be comparatively higher in the soils and surface sediments than in the water. The concentration levels as well as distribution of the selected PAHs varied from season to season, however with no clear pattern. The occurrence pattern of PAHs along the river points to human-related activities as the major input sources of PAHs into Msunduzi water. Paired-up isomeric concentration ratios for surface sediments suggested pyrolysis as the major input source of PAHs, especially at sites closer to the city of Pietermaritzburg (PMB).
\end{abstract}

Keywords: Pyrogenic sources; Water; Soils; Sediments; Msunduzi River
Abbreviations:
PAH: Polycyclic Aromatic Hydrocarbon; LMW: Low Molecular Weight; HMW: High Molecular Weight; TIC: Total Ion Chromatogram; NDA: Nagle Dam; KZN: KwaZulu-Natal; PMB: Pietermaritzburg; HD: Henley Dam; CD: Camp's Drifts; DuTV: Du Toit Viljoen; DWWTP: Darvill Wastewater Treatment Plant; AA: Agricultural Area; MT: Msunduzi Town; JUM: Junction of the Msunduzi and Umgeni; GC-MS: Gas Chromatography-Mass Spectroscopy; DCM: Dichloromethane; LOD: Limit of Detection; LOQ: Limit of Quantification.

\section{Introduction}

Polycyclic Aromatic Hydrocarbons (PAHs) are among the most prevalent pollutants which contaminate air, water, soils and sediments $[1,2]$. These pollutants are mainly generated from incomplete combustion of organically-derived materials (organic wastes, fossils and fuels) at both domestic as well as industrial scales [3,4].

The chemical structures of PAHs are characterised by fused aromatic rings. The least molecular weight $\mathrm{PAH}$ is Naphthalene, which consists of two co-planar benzene rings sharing an edge. The High Molecular Weight PAHs (HMW-PAH) commonly found in polluted environmental matrices contain as many as six-fused aromatic rings. Delocalization of electrons within the extended $\pi$-molecular orbitals of their fused aromatic rings confers thermodynamic stability against biochemical degradation. A combination of chemical stability and hydrophobicity (which increases with molecular mass) causes them to persist in soils and sediments [5]. Although they are not acutely toxic to biota, their persistence and long-range transportation in the wider environment outstand them as higher priority organic pollutants for regular monitoring in the environment [6].

Chemical stability of PAHs and favourable aerodynamics of micro particulates to which they are adsorbed, causes emissions of PAHs to remain in the ground level atmosphere over a long period of time. Air currents can also transport PAHs, particularly the LMW-PAHs to cold and distant areas [7-11]. For example, Rose [12] detected trace levels of PAHs in lake sediments at Svalbard Archipelago, Norway, a location which is remote from possible sources of human-related pollution. Contamination of sediments was attributed to wide range PAHs transportation via air mass currents.

Long-term exposure to high concentrations of PAHs is linked to different health risks such as infertility, cancer and neurotoxicity in mammals [13-15]. For example, PAHs can be biotransformed into reactive epoxide/diols via cytochrome $\mathrm{P} 450$ enzymes-activated routes. The epoxide/diols are capable of forming stable covalent DNA adducts that can lead to genotoxic mutations [16]. Because of this, majority of HMW-PAHs are suspected carcinogens, mutagens and immunosuppressant to different organisms $[14,17]$.

Due to their high oil-to-aqueous partition coefficients, PAHs bioaccumulate easily in adipose tissues of mammals [18]. PAHs can be stored in fatty tissues of predators in the apex of the food-chain for a long period of time and can only be expended through excretive routes. Some of the PAHs metabolites e.g., Polyhydroxylated derivatives are easily excreted as renal and biliary wastes. 
Abdel-Shafy and Mansour [1] pointed out that in the urban environment, PAHs are emitted into the atmosphere and other receiving environmental compartments mainly via processing of crude petroleum (refining of crude oil and synthetic fuels), use of fossil fuels (thermal power generation, domestic heating and burning of organic wastes at unregulated dumpsites, vehicle exhaust emissions) and fallouts (veld/forest fires and volcanic activities). Some of the sources also arise in South Africa's urban and to a smaller extent in the rural environments [19]. Yet, the concentration levels of PAHs in South Africa are not well-known, despite the country being Africa's leading industrialist. To this end, no published work has been reported on the concentration levels of PAHs along the Msunduzi River, KZN, South Africa [20]. However, some isolated studies on PAHs in soils collected from the Isipingo River, Umgeni River and Durban Bay have been reported [21]. A related study has been conducted to quantify PAHs in treated sludge, collected from Darvill, a wastewater treatment plant discharging treated effluent water back into this river [22] Meanwhile, there is a growing degree of ecological pollution along this river [23] and it is therefore necessary to establish a data source on the occurrence of selected PAHs along the Msunduzi water basin, KZN (Figure SI1).

This study was conducted on seven selected PAHs among which are five LMW-PAHs (Naphthalene, Acenaphthylene, Fluorene, Anthracene and Phenanthrene) and two HMW-PAHs (Pyrene and Chrysene) in order to add knowledge and also to build up a prevalence database of LMW-PAHs in water, soils and surface sediments in South Africa. This is in line with the country's signatory obligation to the Stockholm Convention (2001) as promulgated on the long-range trans boundary Air Pollution Protocol on POPs. The selection of the PAHs was based on their solubility in water and their potential toxicological to biota and fauna, carcinogenic, mutagenic and teratogenic effects on human beings and wildlife.

\section{Experimental}

\section{Description of KZN province and location of sampling sites}

KZN is the most populous province of South Africa. It has an estimated population of 10.5 million. It is located between geographical coordinates of $29^{\circ} 0^{\prime} 0^{\prime \prime} \mathrm{S}$ and $31^{\circ} 0^{\prime} 0^{\prime \prime} \mathrm{E}$. It is approximately $95000 \mathrm{~km}^{2}$ and has a coastal climate and a long Indian Ocean shoreline. KZN has several districts which include eThekwini and uMgungundlovu. Durban and PMB are the largest cities in the province. The Msunduzi River basin stretches across the uMgungundlovu District. It is a major tributary of the Umgeni River, the main supply of fresh water to the Durban Metropolitan. The catchment area of the river basin is about $875 \mathrm{~km}^{2}$ and covers a distance of $115 \mathrm{~km}$ to the Umgeni River. It also serves as a major source of drinking water for rural communities residing along the length of the river and irrigation of agricultural crops and small gardens. The Msunduzi River water is also used for recreational sports. Its confluence is at the Elandskop near Bulwer $\left(29^{\circ} 48^{\prime} 0^{\prime \prime} \mathrm{S}\right.$ and $29^{\circ} 46^{\prime} 0^{\prime \prime}$
E, $1500 \mathrm{~m}$ above sea level). It flows into the HD, through Edendale and past the urban built area of $\mathrm{PMB}$, before it joins the Umgeni River. Figure 1 is a map of the KZN Province, showing the six sampling sites along the Msunduzi River, one site on the Umgeni River (i.e., NDA) and another at the junction from which samples were collected.



Figure 1: The location of the six sampling sites along the Msunduzi River, one site on the Umgeni River (i.e., NDA) and another at the junction from which samples were collected.

\section{Sample collection}

In order to establish the occurrence of PAHs along the Msunduzi River basin, water or wastewater, soils and surface sediments were collected at 8 different sampling sites as shown in Figure 1. The samples were collected during the following dates (day/month/year): 26-27/05/2014; 26-27/08/2014; $15-16 / 01 / 2015 \quad$ and 29/09/2015-2/10/2015.

GPS coordinates were utilized to locate the sampling sites. The sampling sites can be conveniently classified into three categories. The $\mathrm{HD}$ site was chosen to represent the upper section of the river. Sites such as the CD and DuTV Bridge and DWWTP are located in the middle reaches of the river. They are located in the urban area of PMB, where the river is at a high risk of receiving organic pollutants due to the associated anthropogenic activities (Figure SI1) [23].

The AA, MT and JUM are sites which are located on the lower reaches of the river. The NDA is the only sampling site located on the Umgeni River. NDA is located upstream of the Umgeni River. This site was selected for comparative assessment with sites located on the Msunduzi River. The details of the geographical coordinates, types of samples and impacting activities done at each site are indicated in Table 1.

\begin{tabular}{|c|c|c|c|c|}
\hline \multirow[b]{2}{*}{ Sites and codes } & \multicolumn{2}{|c|}{ Coordinates } & \multirow[b]{2}{*}{ Sample } & \multirow[b]{2}{*}{ Possible input PAHs } \\
\hline & South & East & & \\
\hline Henley Dam (HD) & $29^{\circ} 38^{\prime} 51^{\prime \prime}$ & $30^{\circ} 17^{\prime} 32^{\prime \prime}$ & Water, soil and sediments & Wild fires, domestic burning \\
\hline Camp's Drifts (CD) & $29^{\circ} 36^{\prime} 47^{\prime \prime}$ & $30^{\circ} 22^{\prime} 36^{\prime \prime}$ & Water, soil and sediments & Domestic and industrial burning, vehicle emissions \\
\hline
\end{tabular}




\begin{tabular}{|l|l|l|l|l|}
\hline Du Toit Viljoen (DuTV) Bridge & $29^{\circ} 35^{\prime} 15^{\prime \prime}$ & $30^{\circ} 24^{\prime} 00^{\prime \prime}$ & Water, soil and sediments & Domestic and commercial activities \\
\hline $\begin{array}{l}\text { Darvill Wastewater Treatment } \\
\text { Plant (DWWTP) Inlet }\end{array}$ & $29^{\circ} 36^{\prime} 15^{\prime \prime}$ & $30^{\circ} 25^{\prime} 52^{\prime \prime}$ & Water and wastewater & $\begin{array}{l}\text { Domestic and industrial } \text { wastes from the city of } \\
\text { Piermaritzburg }\end{array}$ \\
\hline $\begin{array}{l}\text { Darvill Wastewater Treatment } \\
\text { Plant (DWWTP) Outlet }\end{array}$ & $29^{\circ} 36^{\prime} 15^{\prime \prime}$ & $30^{\circ} 25^{\prime} 52^{\prime \prime}$ & Water and wastewater & Residual organic particulates in the discharged effluent \\
\hline Agricultural Area (AA) & $29^{\circ} 36^{\prime} 40^{\prime \prime}$ & $30^{\circ} 33^{\prime} 32^{\prime \prime}$ & Water, soil and sediments & $\begin{array}{l}\text { Wild fires, organic particulates from application of manure, } \\
\text { depon the river course way }\end{array}$ \\
\hline Msunduzi Town (MT) & $29^{\circ} 39^{\prime} 40^{\prime \prime}$ & $30^{\circ} 38^{\prime} 10^{\prime \prime}$ & Water, soil and sediments & Agricultural, shanty industries and domestic activities \\
\hline $\begin{array}{l}\text { Junction of the Msunduzi and } \\
\text { Umgeni Rivers (JUM) }\end{array}$ & $29^{\circ} 37^{\prime} 16^{\prime \prime}$ & $30^{\circ} 40^{\prime} 46^{\prime \prime}$ & Water, soil and sediments & Deposition of polluted sediments \\
\hline \begin{tabular}{l} 
Nagle Dam (NDA) \\
\hline
\end{tabular} & $29^{\circ} 35^{\prime} 1^{\prime \prime}$ & $30^{\circ} 37^{\prime} 1^{\prime \prime}$ & Water, soil and sediments & Deposition of polluted sediments and agricultural activities \\
\hline
\end{tabular}

Table 1: Sampling sites along the Msunduzi River, their site codes, GPS coordinates and possible input sources of PAHs.

Conductivity (Handylab LF12 Portable Conductivity-Meter, Schott Instruments, $\mathrm{GmbH}$ ), $\mathrm{pH}$, ambient and water temperatures (IQ150NP $\mathrm{pH} / \mathrm{mV} /$ thermo-meter, Hach, USA) were recorded on site. Results are shown as Supplementary Data, Figure SI1. All samples were collected in amber glass bottles which had been pre-washed with water and soap then rinsed with distilled water and $n$-hexane. Surface water and wastewater samples were filled into $1 \mathrm{~L}$ bottles fitted with screw caps lined with Teflon. Surface sediments and soils (500 g) were collected into bottles using a stainless steel grab sampler. All samples were immediately placed in a cooler box and transported to the laboratory where they were stored in a refrigerator at $4^{\circ} \mathrm{C}$ until further analysis.

\section{Extraction of PAHs and analysis}

Liquid-liquid extraction of PAHs from the water and the wastewater samples: All water samples were extracted without filtering to reflect exposure levels to animals drinking it as well as human users. A separating funnel was used for the extraction of PAHs from water samples [24]. The extraction of water samples and their spiked duplicates for PAHs followed a common procedure.

Soxhlet extraction of PAHs from soils and sediments: The soils and surface sediments were removed from the fridge and spread on Aluminium foils and left to air-dry in a dark room. The dried soils and surface sediments were screened through a $2 \mathrm{~mm}$ sieve to initially remove debris and plant material. The segregated subsamples were then pulverized with a mortar and pestle to pass through a less than $150 \mu \mathrm{m}$ sieve. The powders were kept in amber glass bottles that had been pre-soaked in $10 \% \mathrm{HNO}_{3}$ and rinsed with distilled water and nhexane.

The soils and sediments were extracted using the Soxhlet extraction [25] Weighed duplicates of surface sediments or soils $(10 \mathrm{~g})$ were mixed thoroughly with approximately $2 \mathrm{~g}$ portions of anhydrous Sodium sulphate and $2 \mathrm{~g}$ of Copper powder. The mixture was wrapped onto a filter paper and inserted into the cellulose extraction thimble and covered with cotton wool. The thimble was placed into the main Soxhlet chamber and fitted to a $250 \mathrm{ml}$ round bottom flask containing $100 \mathrm{ml}$ of an equal mixture of chromatographic grade DCM/n-hexane. A condenser was then attached. The samples were extracted for 16 hours under reflux. The crude extracts were concentrated to a volume of nearly $5 \mathrm{ml}$ using a rotary vacuum evaporator. The concentrates were purified by short-column silica gel chromatography using nhexane as the eluting solvent. The eluates were filtered through a 0.45 $\mu \mathrm{m}$ membrane (Millipore) and reduced to a final volume $(2 \mathrm{ml})$ using flushing nitrogen gas. The purified extracts (in sealed vials) were kept in the fridge until analysis by GC-MS.

GC-MS analysis of PAHs: The analysis of PAHs was carried out on a GC-MS (QP-2010 series (Shimadzu, Japan) Spectrometer. The injector port was set at $300^{\circ} \mathrm{C}$. The oven temperature was held initially at $40^{\circ} \mathrm{C}$ and then increased to $120^{\circ} \mathrm{C}$ at $25^{\circ} \mathrm{C} \mathrm{min}-1$, then to $160^{\circ} \mathrm{C}$ at $10^{\circ} \mathrm{C}$ $\mathrm{min}^{-1}$ and finally to $300^{\circ} \mathrm{C}$ at $5^{\circ} \mathrm{C} \mathrm{min}^{-1}$.

Purified extracts $(10 \mu \mathrm{l})$ were injected without splitting. The PAHs were separated on an Rxi-5Sil-MS capillary column $(30 \mathrm{~m} \times 0.25 \mathrm{~mm}$ i.d. $\times 0.25 \mu \mathrm{m}$ film thickness of 1,4-bis(dimethyl siloxy) phenylene dimethyl polysiloxane). Ultrapure helium (99.99\%) was used as the carrier gas. The detector was scanned over a limited mass range in order to attain a sensitivity gain. PAHs were ionized using a $70 \mathrm{eV}$ electron beam. The ions were separated on a single quadrupole and detected by an electron multiplier detector. The detector was operated in the Selected Ion Monitoring (SIM) acquisition mode.

Reagents, standards and analysis: The eight PAH standards of Naphthalene (99.0\% purity), Acenaphthylene (95\% purity), Fluorene (98\% purity), Phenanthrene, Anthracene, Pyrene, Chrysene and Deuterated naphthalene-d8 (99.0\% purity), DCM ( $\geq 99.8 \%$ purity) and n-hexane ( $\geq 99 \%$ purity), Sodium sulphate and Copper powder (particle size $<63 \mu \mathrm{m}$ ) were purchased from Sigma-Aldrich (Steinheim, Germany).

Preparation of calibration solutions and quality assurance of analysis: The PAHs were quantified by external calibration incorporating a surrogate standard (naphthalene-d8) with a common upper bound range of $2 \mu \mathrm{g} \mathrm{ml}^{-1}$. Each standard was injected three times and the mean intensity ratio against the naphthalene- $d 8$ calculated. The mean intensity ratios at each concentration level of each PAH was plotted against the concentration of the PAH.

The LOD and LOQ were estimated from the calibration slope using signal-to-noise ratios of 3 and 10, respectively. The estimated values of the LOD and LOQ are presented in Table SI1 (Supporting Information). To evaluate the efficiency of extracting the targeted PAHs and their detection by GC-MS, samples of water, soils or surface sediments in duplicates were spiked with known amounts of the $7 \mathrm{PAH}$ standards and naphthalene-d8 and left to equilibrate for 7 days in the dark. The non-spiked and the equilibrated spiked split portions were extracted as described for the field samples and analysed by GC-MS. 
Exemplary chromatographs for spiked sample are shown in Figures SI2 and SI3 (Supplementary Data).

The percentage recovery of each PAH was calculated by subtracting the amount measured from the non-spiked duplicates at the set molecular ion peaks. Recovery data is summarized in Table SI2 (Supplementary Information).

The identification of each $\mathrm{PAH}$ was by comparing its retention time in the TIC of the samples to that of the standards. Typical TIC, mass spectra and confirmation ions of PAH compounds is presented in Figures SI2 and SI3 (Supporting Information). Calibration equations incorporating internal standardization were used to quantify PAHs in the samples.

\section{Results and Discussion}

\section{Estimation of LOD, LOQ and Quality Control (QC) of analysis}

The LOD, LOQ and recoveries for the 7 PAHs are presented in Table SI2. The LODs by GC-MS ranged from 0.2 to $0.8 \mathrm{ng} \mathrm{L}^{-1}$ for water and from 0.1 to $0.7 \mathrm{ng} \mathrm{g}^{-1}$ for soil and sediment samples while the LOQs ranged from 1.0 to $1.3 \mathrm{ng} \mathrm{L}^{-1}$ for water and from 1.0 to $2.4 \mathrm{ng} \mathrm{g}^{-1}$ for soil and sediment samples (Table SI2). The calculated percentage recoveries are also summarized in Table SI2. On the basis of the recovery data on the spiked samples, the analytical procedures for water, soils and sediments were adapted for the determination of the concentration of the targeted PAHs in the field samples.

\section{Conductivity, $\mathrm{pH}$ and temperature of the Msunduzi River water}

Table SI3 presents the measured data on conductivity, $\mathrm{pH}$ and temperature of water collected during autumn and winter seasons of 2014 and the summer and spring seasons of 2015. The water temperature was in the range $12^{\circ} \mathrm{C}$ to $26^{\circ} \mathrm{C}$ in the autumn and winter of 2014. Higher temperatures (ranging from $22^{\circ} \mathrm{C}$ to $28^{\circ} \mathrm{C}$ ) were measured for summer 2015. The average ambient temperature was $25.87 \pm 0.02^{\circ} \mathrm{C}$ for the autumn, $28.96 \pm 0.05^{\circ} \mathrm{C}$ for the winter, $21.02 \pm$ $0.03^{\circ} \mathrm{C}$ for the spring and $31.86 \pm 0.05^{\circ} \mathrm{C}$ for the summer seasons. The ranges are typical of surface waters in the subtropics.

The $\mathrm{pH}$ of the water was also measured on site. Water $\mathrm{pH}$ indicates the level of acidity or alkalinity. In cases where there is a minimum external injection of acidic or basic wastes, the $\mathrm{pH}$ of the natural water depends mainly on the chain equilibria involving dissolution of carbonates from the bedrocks (lime stones and shales), $\mathrm{CO}_{3}{ }^{2-} / \mathrm{HCO}_{3}{ }^{-}$ buffer system that forms as well as absorption and gasification of $\mathrm{CO}_{2}$. The $\mathrm{pH}$ of the water is also affected by input loads of acidic organic components. During the autumn of 2014, the $\mathrm{pH}$ of the river water and wastewater was within the normal range (6.0-7.5) for natural surface water. However, a slight rise in water $\mathrm{pH}$ ranging between 7.32 and 9.02 was recorded in winter. The water from sites located on the lower reaches of the river, such as the JUM and the NDA had slightly higher $\mathrm{pH}$ values, which may be attributed to hydrolysis of organic-derived wastes in addition to the natural $\mathrm{pH}$ buffering system of the river water.

The persistence and stabilization of organic pollutants such as PAHs in surface water depends on physical parameters of the water such as Total Dissolved Solids (TDS) and the fraction of ionisable particulate matter on which they can adsorb. These can be tested reliably by measuring the conductivity of the water. The conductivity of the Msunduzi water varied between 90.2 and $946 \mu \mathrm{cm}^{-1}$ and generally increased from the source of the river up to the DWWTP Outlet and decreased gradually up to the mouth of the river. Peaking of conductivity at DWWTP Outlet may be due to the partial release of a cocktail of dissolved ionic species and pollutants in the treated wastewater from the city of PMB. The overall variation of conductivity along the river also depended on ambient temperature on the day of sampling.

Slightly higher conductivity values were observed in winter of 2014 and spring of 2015 when compared to autumn and summer seasons of the respective years. This could be due to concentration effects in winter and spring, both seasons of which fall in the dry period in the subtropics.

\section{Concentration of PAHs in water and waste water samples}

The concentration of 7 PAHs in water samples collected along the Msunduzi River on the following dates (season): 26-27/05/2014 (autumn), 26-27/08/2014 (winter), 15-16/01/2015 (summer) and $29 / 09 / 2015-2 / 10 / 2015$ (spring) as well as the summed concentrations $\left(\Sigma_{7}[\mathrm{PAH}]\right)$ at each site are presented in Tables $2 \mathrm{a}-2 \mathrm{~d}$ and graphed in Figure 2a-2d.

\begin{tabular}{|c|c|c|c|c|c|c|c|c|}
\hline \multirow[b]{2}{*}{ Sites } & \multicolumn{5}{|l|}{ LMW-PAHs } & \multicolumn{2}{|l|}{ HMW-PAHS } & \multirow[b]{2}{*}{$\sum_{7}[\mathrm{PAH}]$} \\
\hline & NA & $\mathrm{ACY}$ & FLUO & PHEN & ANTH & PYR & CHRY & \\
\hline HD & $13.52 \pm 0.01$ & $34.31 \pm 0.03$ & $39.34 \pm 0.02$ & $40.22 \pm 0.03$ & $57.78 \pm 0.02$ & ND & $53.55 \pm 0.03$ & $238.7 \pm 0.2$ \\
\hline$C D$ & $28.34 \pm 0.02$ & $120.11 \pm 0.11$ & $118.83 \pm 0.01$ & $156.21 \pm 0.13$ & $140.22 \pm 0.01$ & $46.43 \pm 0.02$ & $74.17 \pm 0.04$ & $684.3 \pm 0.7$ \\
\hline DuTV & $17.38 \pm 0.01$ & $40.44 \pm 0.03$ & $40.31 \pm 0.03$ & ND & $70.72 \pm 0.01$ & ND & $550.08 \pm 0.20$ & $718.9 \pm 0.3$ \\
\hline DWWTP Inlet & $25.42 \pm 0.01$ & $39.70 \pm 0.02$ & ND & ND & $54.07 \pm 0.01$ & $12.05 \pm 0.01$ & $45.56 \pm 0.03$ & $176.8 \pm 0.1$ \\
\hline DWWTP Outlet & $47.67 \pm 0.04$ & $30.40 \pm 0.01$ & ND & ND & $69.33 \pm 0.06$ & $506.93 \pm 0.04$ & $41.25 \pm 0.03$ & $695.6 \pm 0.2$ \\
\hline AA & $14.52 \pm 0.01$ & $17.76 \pm 0.01$ & $15.24 \pm 0.01$ & $41.10 \pm 0.03$ & $40.60 \pm 0.02$ & $47.76 \pm 0.03$ & $46.91 \pm 0.04$ & $226.9 \pm 0.3$ \\
\hline MT & $3.30 \pm 0.01$ & ND & $67.17 \pm 0.04$ & ND & ND & $11.50 \pm 0.01$ & $3.60 \pm 0.02$ & $85.6 \pm 0.2$ \\
\hline
\end{tabular}


Citation: Munyengabe A, Mambanda A, Moodley B (2017) Polycyclic Aromatic Hydrocarbons in Water, Soils and Surface Sediments of the Msunduzi River. J Environ Anal Chem 4: 227. doi:10.4172/2380-2391.1000227

Page 5 of 13

\begin{tabular}{|l|l|l|l|l|l|l|l|l|}
\hline JUM & $51.38 \pm 0.10$ & $49.47 \pm 0.05$ & $62.90 \pm 0.04$ & $115.91 \pm 0.02$ & $74.41 \pm 0.01$ & $26.03 \pm 0.03$ & $84.51 \pm 0.01$ & $464.6 \pm 0.3$ \\
\hline NDA & $9.40 \pm 0.01$ & $3.07 \pm 0.04$ & ND & ND & ND & ND & ND & $12.5 \pm 0.1$ \\
\hline
\end{tabular}

Table 2a: Concentrations of the 7 PAHs in the water (ng L ${ }^{-1} \pm$ SD) at each site during autumn of 2014, where, ND=Not Detected, LMWPAHs=Lower Molecular Weight PAHs, HMW-PAHs-Higher Molecular Weight PAHs and the $\Sigma_{7}[\mathrm{PAH}]=$ the sum of concentrations of seven PAHs found at each site. LOD values are shown in Table SI1. SD=Standard Deviation.

\begin{tabular}{|l|l|l|l|l|l|l|l|l|}
\hline \multirow{2}{*}{ Sites } & \multicolumn{2}{l}{ LMW-PAHs } & \multicolumn{3}{l}{ HMW-PAHs } \\
\cline { 2 - 8 } & NA & ACY & FLUO & PHEN & ANTH & PYR & CHRY & Z7[PAH] \\
\hline HD & $15.45 \pm 0.01$ & $36.23 \pm 0.04$ & $46.67 \pm 0.03$ & $35.87 \pm 0.02$ & $54.32 \pm 0.06$ & ND & $44.27 \pm 0.04$ & $232.8 \pm 0.2$ \\
\hline CD & $22.70 \pm 0.02$ & $81.46 \pm 0.11$ & $51.35 \pm 0.05$ & $160.16 \pm 0.19$ & $80.50 \pm 0.04$ & $26.07 \pm 0.05$ & $42.21 \pm 0.04$ & $464.5 \pm 0.8$ \\
\hline DuTV & $9.92 \pm 0.01$ & $10.75 \pm 0.03$ & ND & $28.60 \pm 0.04$ & $21.78 \pm 0.03$ & ND & $2.30 \pm 0.02$ & $73.4 \pm 0.1$ \\
\hline DWWTP Inlet & $34.83 \pm 0.01$ & $29.66 \pm 0.01$ & ND & ND & $14.27 \pm 0.01$ & $303.77 \pm 0.20$ & $24.85 \pm 0.02$ & $407.4 \pm 0.5$ \\
\hline DWWTP Outlet & $42.73 \pm 0.04$ & $40.54 \pm 0.05$ & ND & ND & $40.90 \pm 0.08$ & $376.02 \pm 0.29$ & $53.43 \pm 0.06$ & $553.6 \pm 0.6$ \\
\hline AA & $14.56 \pm 0.01$ & ND & $13.24 \pm 0.01$ & $66.64 \pm 0.12$ & ND & $20.81 \pm 0.04$ & $40.34 \pm 0.04$ & $155.6 \pm 0.2$ \\
\hline MT & $8.33 \pm 0.02$ & ND & ND & $32.12 \pm 0.11$ & $31.43 \pm 0.02$ & ND & $31.54 \pm 0.09$ & $103.4 \pm 0.3$ \\
\hline JUM & $10.97 \pm 0.01$ & $28.42 \pm 0.01$ & $22.84 \pm 0.01$ & $42.56 \pm 0.03$ & ND & ND & $17.34 \pm 0.01$ & $122.1 \pm 0.1$ \\
\hline NDA & $6.23 \pm 0.01$ & ND & $14.54 \pm 0.02$ & $20.75 \pm 0.01$ & $15.44 \pm 0.01$ & ND & $26.66 \pm 0.01$ & $83.6 \pm 0.1$ \\
\hline
\end{tabular}

Table 2b: Concentrations of the 7 PAHs in the water (ng L-1 \pm SD) at each site during the winter of 2014, where, ND=Not Detected, LMWPAHs=Lower Molecular Weight PAHs, HMW-PAHs=Higher Molecular Weight PAHs and the $\Sigma_{7}[\mathrm{PAH}]=$ the sum of concentrations of seven PAHs found at each site. LOD values are shown in Table SI1. SD=Standard Deviation.

\begin{tabular}{|c|c|c|c|c|c|c|c|c|}
\hline \multirow[b]{2}{*}{ Sites } & \multicolumn{5}{|l|}{ LMW-PAHs } & \multicolumn{2}{|l|}{ HMW-PAHs } & \multirow[b]{2}{*}{$\Sigma_{7}[\mathrm{PAH}]$} \\
\hline & NA & ACY & FLUO & PHEN & ANTH & PYR & CHRY & \\
\hline $\mathrm{HD}$ & $6.42 \pm 0.01$ & $7.55 \pm 0.01$ & $8.45 \pm 0.03$ & $1294.73 \pm 0.39$ & $38.19 \pm 0.02$ & $25.49 \pm 0.01$ & ND & $1381 \pm 0.5$ \\
\hline$C D$ & $10.52 \pm 0.01$ & $33.34 \pm 0.02$ & $125.53 \pm 0.11$ & $448.20 \pm 0.04$ & $67.30 \pm 0.01$ & $114.50 \pm 0.05$ & $154.56 \pm 0.01$ & $954 \pm 0.3$ \\
\hline DuTV & $10.46 \pm 0.02$ & $71.71 \pm 0.04$ & $30.15 \pm 0.02$ & $374.28 \pm 0.03$ & $31.99 \pm 0.01$ & $44.07 \pm 0.02$ & $8.20 \pm 0.01$ & $571 \pm 0.1$ \\
\hline DWWTP Inlet & $10.17 \pm 0.01$ & $11.67 \pm 0.01$ & ND & ND & ND & $1727.2 \pm 0.27$ & ND & $1750 \pm 0.3$ \\
\hline DWWTP Outlet & $14.90 \pm 0.01$ & $149.36 \pm 0.08$ & $78.33 \pm 0.02$ & $285.98 \pm 0.12$ & $14.12 \pm 0.01$ & $36.72 \pm 0.01$ & $5.34 \pm 0.03$ & $585 \pm 0.3$ \\
\hline AA & $9.72 \pm 0.03$ & $20.46 \pm 0.01$ & $11.25 \pm 0.01$ & $162.92 \pm 0.02$ & $52.24 \pm 0.03$ & $22.20 \pm 0.02$ & $4.70 \pm 0.01$ & $284 \pm 0.1$ \\
\hline MT & $11.04 \pm 0.23$ & $56.31 \pm 0.04$ & $39.87 \pm 0.02$ & $285.07 \pm 0.16$ & $70.85 \pm 0.02$ & $159.27 \pm 0.13$ & $30.18 \pm 0.03$ & $653 \pm 0.6$ \\
\hline JUM & $9.97 \pm 0.01$ & $38.00 \pm 0.02$ & $57.46 \pm 0.01$ & $281.66 \pm 0.03$ & $118.35 \pm 0.01$ & $126.38 \pm 0.03$ & $18.73 \pm 0.01$ & $651 \pm 0.1$ \\
\hline NDA & $10.44 \pm 0.01$ & $73.50 \pm 0.01$ & $149.67 \pm 0.07$ & $248.05 \pm 0.12$ & ND & $37.12 \pm 0.03$ & $7.68 \pm 0.01$ & $527 \pm 0.3$ \\
\hline
\end{tabular}

Table 2c: Concentrations of the 7 PAHs in the water (ng L ${ }^{-1} \pm$ SD) at each site during the summer of 2015, ND=Not Detected, LMWPAHs=Lower Molecular Weight PAHs, HMW-PAHs=Higher Molecular Weight PAHs and the $\Sigma_{7}[\mathrm{PAH}]=$ the sum of concentrations of seven PAHs found at each site. LOD values are shown in Table SI1. SD=Standard Deviation.

\begin{tabular}{|c|c|c|c|c|c|c|c|c|}
\hline \multirow[b]{2}{*}{ Sites } & \multicolumn{5}{|c|}{ LMW-PAHs } & \multicolumn{2}{|c|}{ HMW-PAHS } & \multirow[b]{2}{*}{$\Sigma_{7}[\mathrm{PAH}]$} \\
\hline & NA & ACY & FLUO & PHEN & ANTH & PYR & CHRY & \\
\hline
\end{tabular}


Page 6 of 13

\begin{tabular}{|l|l|l|l|l|l|l|l|l|}
\hline HD & $16.28 \pm 0.82$ & $152.45 \pm 0.07$ & $130.92 \pm 0.14$ & $42.03 \pm 0.05$ & $88.85 \pm 0.08$ & $13.31 \pm 0.01$ & $18.24 \pm 0.02$ & $462.1 \pm 1.2$ \\
\hline CD & $36.60 \pm 0.02$ & $314.97 \pm 0.23$ & $279.02 \pm 0.21$ & $211.64 \pm 0.15$ & $99.25 \pm 0.08$ & ND & $25.47 \pm 0.02$ & $967 \pm 0.7$ \\
\hline DuTV & $14.13 \pm 0.01$ & $81.20 \pm 0.02$ & $13.97 \pm 0.33$ & $22.32 \pm 0.02$ & ND & $5.06 \pm 0.02$ & ND & $137 \pm 0.4$ \\
\hline DWWTP Inlet & $151.50 \pm 0.13$ & ND & $74.61 \pm 0.01$ & $55.95 \pm 0.09$ & ND & ND & ND & $282 \pm 0.2$ \\
\hline DWWTP Outlet & $4.67 \pm 0.49$ & $90.78 \pm 0.90$ & $22.32 \pm 0.43$ & $37.70 \pm 0.05$ & $21.41 \pm 0.05$ & $20.28 \pm 0.02$ & $11.26 \pm 0.01$ & $208.4 \pm 1.9$ \\
\hline AA & $12.00 \pm 0.06$ & $178.55 \pm 0.15$ & $169.76 \pm 0.17$ & $107.85 \pm 0.16$ & $96.20 \pm 0.17$ & $15.17 \pm 0.01$ & ND & $579.5 \pm 0.7$ \\
\hline MT & $0.67 \pm 0.12$ & $59.40 \pm 0.06$ & $60.93 \pm 0.06$ & $94.84 \pm 0.02$ & $23.35 \pm 0.03$ & ND & $1.70 \pm 0.04$ & $240.9 \pm 0.3$ \\
\hline JUM & $61.25 \pm 0.04$ & $689.63 \pm 0.33$ & $627.95 \pm 0.55$ & $156.43 \pm 0.08$ & $228.30 \pm 0.11$ & ND & $35.58 \pm 0.02$ & $1799 \pm 1$ \\
\hline NDA & $11.65 \pm 0.01$ & $19.61 \pm 0.02$ & ND & $41.36 \pm 0.06$ & ND & ND & $1.80 \pm 0.01$ & $74 \pm 0.1$ \\
\hline
\end{tabular}

Table 2d: Concentrations of the 7 PAHs in the water (ng L ${ }^{-1} \pm$ SD) at each site during the spring of 2015, where, ND=Not Detected, LMWPAHs=Lower Molecular Weight PAHs, HMW-PAHs=Higher Molecular Weight PAHs and the $\Sigma_{7}[\mathrm{PAH}]=$ the sum of concentrations of seven PAHs found at each site. LOD values are shown in Table SI1. SD=Standard deviation.

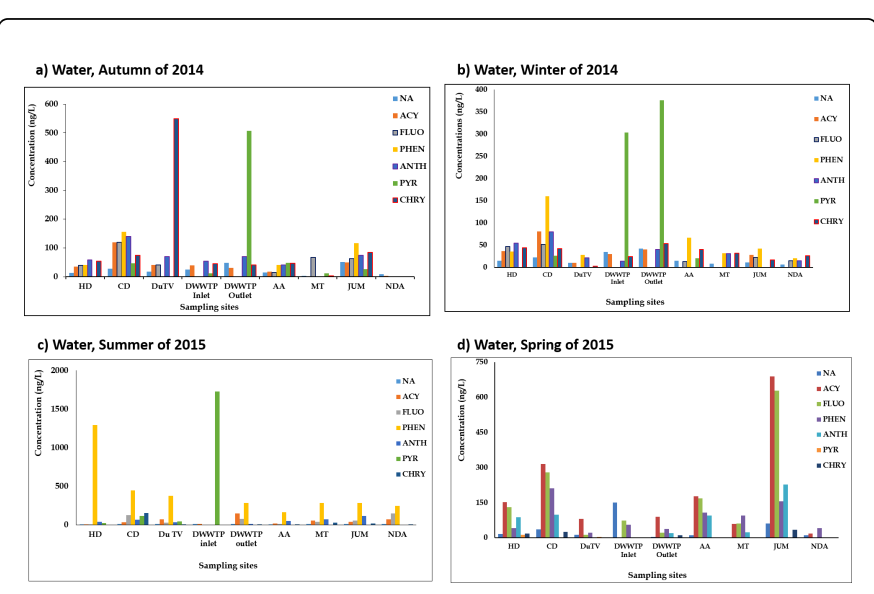

Figure 2: a-d) Seasonal distribution (autumn and winter of 2014; summer and spring of 2015) of the selected PAHs in the water and wastewater from sites along the Msunduzi River.

Data in Tables $2 \mathrm{a}-2 \mathrm{~d}$ reveals that PAHs were positively identified at concentrations above their detection limits (Table SI2) in most water and wastewater samples collected along the Msunduzi River on the period spanning autumn of 2014 to spring of 2015.

Looking at the calculated $\Sigma_{7}[\mathrm{PAH}]_{\text {water }}$ values (last column of the Tables 2a-2d), the incidence of PAHs in the surface water and wastewater samples varied significantly among the sites. The summed concentration of PAHs ranged between $12.5 \mathrm{ng} \mathrm{L}^{-1}$ (at NDA) and 1799 $\mathrm{ng} \mathrm{L^{-1 }}$ (JUM) with a summed concentration average of $810 \pm 0.3 \mathrm{ng} \mathrm{L}^{-1}$ for the entire study period. There is no clear pattern on the incidence nor the compositional profile of PAHs detected in the water samples. However, slightly higher $\Sigma_{7}[\mathrm{PAH}]_{\text {water }}$ levels were recorded in summer of 2014 compared to the other seasons. This may be due to increased contamination inputs from surface run off into the river during the rainy summer season.

During the study period, significantly high levels of one or two of the selected PAHs were noted at some of the sites. For example, during autumn of 2014, water collected at CD (684.3 $\left.\mathrm{ng} \mathrm{L}^{-1}\right)$; DuTV (550.1 ng
$\mathrm{L}^{-1}$ ) and DWWTP outlet (503.9 $\mathrm{ng} \mathrm{L}^{-1}$ ) was significantly contaminated with either PYR or CHRY. In winter of the same year, waste water at Darvill's inlet (303 $\mathrm{ng} \mathrm{L}^{-1}$ ) and outlet (376 $\left.\mathrm{ng} \mathrm{L}^{-1}\right)$ sampling points was contaminated with relatively higher levels of PYR compared to the rest of the sites. In summer of 2015, the influent at Darvill was significantly contaminated with PRY (1727 ng L $\mathrm{L}^{-1}$ ) while the concentration of PHEN was also high for all sampling sites, peaking at $\mathrm{HD}$ (a background control site). In spring of 2015, water at JUM had high concentration levels of ACY (627 $\left.\mathrm{ng} \mathrm{L}^{-1}\right)$ and FLUO (627 $\left.\mathrm{ng} \mathrm{L}^{-1}\right)$.

In the four seasons covering the study period, sites upstream (HD) or downstream (MT, JUM) of the Msunduzi River recorded significantly lower $\Sigma_{7}[\mathrm{PAH}]_{\text {water }}$ values compared to those located on the middle reaches of the river. Sites upstream of the Msunduzi River presented the background concentration levels of PAHs from natural inputs such as atmospheric fallouts or wet deposition after natural veld fires commonly occurring in KZN during the period covering the autumn and spring. Sites downstream of the river were expected to have significantly higher concentration levels than those located upstream due to deposition. The relatively lower levels may be due to the dilution effects. Sites located near the city of PMB (CD, DuTV, DWWTP) were the worst contaminated (as $\Sigma_{7}[\mathrm{PAH}]_{\text {water }}$ ) with the selected PAHs. At CD, high incidence of contamination could be due to suspected illegal dumping or eventual draining of industrial as well as domestic wastes into the river. At DuTV, contamination of water by PAHs is likely to be due to vehicle emissions onto the surrounding areas from the overhead and busy N3 National Freeway. As a result, contamination of nearby soils presents a higher chance of leaching of these compounds down into the Msunduzi River water. Suspected illegal dumping from the nearby Wilton shanty town and industries may also be another contributing factor.

At the DWWTP, influent sewer wastes are biochemically treated, targeting removal of excess inorganic nutrients and trace metal elements. Only treated effluents meeting strict standards for discharging are channeled back into the Msunduzi River. This plant treats about $8.1 \times 10^{7} \mathrm{~L}$ of sewer wastes per day. Because South Africa is characterized by a low and highly variable rainfall pattern (arid to semi-arid country), discharge of effluent which may be contaminated with residual organic compounds which include PAHs may reintroduce them into the down reaches of the river. This causes an 
Citation: Munyengabe A, Mambanda A, Moodley B (2017) Polycyclic Aromatic Hydrocarbons in Water, Soils and Surface Sediments of the

Page 7 of 13

increase in their concentration levels, especially on suspended particulates and sediments downstream of the point of discharge into the river [23].

Only a few comprehensive studies [26-30] have been done on PAH concentrations in the wastewater and water in South Africa. In a recent study [30] reporting the incidence of PAHs in river water and wastewater samples collected from the Vhembe district, South Africa, PAHs were detected in the range of $13.2-26.4 \mathrm{mg} \mathrm{L}^{-1}$. The reported concentration levels are significantly higher than those measured in this study.

The concentration range of PAHs found in the water samples from this study is higher than that reported for water from Hartbeespoort
Dam, South Africa by Amdany et al. [29] but significantly lower than that reported for water from Almendares River in Cuba [31] and two studies on the Daliao River watershed in China $[32,33]$.

\section{Concentration of PAHs in soils collected from the banks of the river}

The concentration levels of PAHs in soils collected from the banks of the Msunduzi River and NDA during the autumn and winter of 2014 as well as summer and spring of 2015 are presented in Tables $3 a-3 d$ and Figure 3a-3d.

\begin{tabular}{|c|c|c|c|c|c|c|c|c|}
\hline \multirow[b]{2}{*}{ Sites } & \multicolumn{5}{|l|}{ LMW-PAHs } & \multicolumn{2}{|l|}{ HMW-PAHs } & \multirow[b]{2}{*}{$\Sigma_{7}[\mathrm{PAH}]$} \\
\hline & NA & ACY & FLUO & PHEN & ANTH & PYR & CHRY & \\
\hline $\mathrm{HD}$ & $3.77 \pm 0.73$ & $25.72 \pm 4.02$ & $4.55 \pm 0.12$ & $2.52 \pm 0.95$ & $1.76 \pm 0.09$ & $2.14 \pm 1.44$ & $13.39 \pm 1.17$ & $53.9 \pm 9$ \\
\hline$C D$ & $0.26 \pm 0.01$ & $1.56 \pm 0.62$ & $1.14 \pm 0.08$ & $9.03 \pm 1.04$ & $2.57 \pm 0.44$ & $4.78 \pm 1.06$ & $4.10 \pm 0.10$ & $23.45 \pm 3.0$ \\
\hline DuTV & $0.29 \pm 0.03$ & $0.45 \pm 0.02$ & $1.45 \pm 0.09$ & $5.97 \pm 0.54$ & $3.52 \pm 0.93$ & $1.06 \pm 0.27$ & $3.89 \pm 1.12$ & $16.65 \pm 3.0$ \\
\hline AA & $3.37 \pm 0.28$ & $39.59 \pm 6.61$ & $8.67 \pm 1.02$ & $34.59 \pm 5.01$ & $7.67 \pm 0.17$ & $2.86 \pm 0.44$ & $12.64 \pm 2.43$ & $109.4 \pm 16$ \\
\hline MT & $4.88 \pm 1.43$ & $9.23 \pm 2.34$ & $1.18 \pm 0.07$ & $26.89 \pm 4.18$ & $1.30 \pm 0.03$ & $6.66 \pm 2.32$ & $4.77 \pm 1.67$ & $55.0 \pm 12$ \\
\hline JUM & $0.25 \pm 0.02$ & $0.75 \pm 0.02$ & $0.17 \pm 0.05$ & $1.30 \pm 0.20$ & $0.09 \pm 0.02$ & $0.30 \pm 0.08$ & $0.35 \pm 0.08$ & $3.2 \pm 0.5$ \\
\hline NDA & $0.58 \pm 0.04$ & $1.10 \pm 0.02$ & $3.17 \pm 0.13$ & ND & ND & ND & $3.43 \pm 0.16$ & $8.3 \pm 0.4$ \\
\hline
\end{tabular}

Table 3a: Concentrations of the 7 PAHs in the soils $\left(\mu \mathrm{g} \mathrm{g}^{-1} \pm \mathrm{SD}\right)$ at each site during the autumn of 2014 .

\begin{tabular}{|c|c|c|c|c|c|c|c|c|}
\hline \multirow[b]{2}{*}{ Sites } & \multicolumn{5}{|l|}{ LMW-PAHs } & \multicolumn{2}{|l|}{ HMW-PAHs } & \multirow[b]{2}{*}{$\sum_{7}[\mathrm{PAH}]$} \\
\hline & NA & ACY & FLUO & PHEN & ANTH & PYR & CHRY & \\
\hline HD & $0.25 \pm 0.05$ & $0.41 \pm 0.09$ & $0.13 \pm 0.01$ & $1.25 \pm 0.04$ & $0.23 \pm 0.09$ & ND & $0.39 \pm 0.03$ & $2.67 \pm 0.3$ \\
\hline$C D$ & $0.11 \pm 0.09$ & ND & ND & $2.69 \pm 0.10$ & $0.62 \pm 0.27$ & $1.81 \pm 0.46$ & $2.00 \pm 0.54$ & $7.26 \pm 1.4$ \\
\hline DuTV & $0.12 \pm 0.10$ & $0.51 \pm 0.08$ & $0.87 \pm 0.05$ & $6.74 \pm 2.78$ & $1.21 \pm 0.12$ & $2.76 \pm 0.08$ & $1.90 \pm 0.36$ & $14.2 \pm 3.5$ \\
\hline AA & $2.87 \pm 0.53$ & $28.97 \pm 4.46$ & $4.10 \pm 1.05$ & $27.35 \pm 5.82$ & $3.35 \pm 1.82$ & $0.90 \pm 0.73$ & $9.77 \pm 2.32$ & $77.3 \pm 17$ \\
\hline MT & $0.06 \pm 0.06$ & $1.06 \pm 0.65$ & $0.34 \pm 0.20$ & $1.43 \pm 0.81$ & ND & $0.34 \pm 0.34$ & $1.95 \pm 1.09$ & $5.2 \pm 3.0$ \\
\hline JUM & $0.24 \pm 0.03$ & ND & ND & $5.41 \pm 1.99$ & $1.04 \pm 0.77$ & $0.91 \pm 0.76$ & $1.02 \pm 0.72$ & $8.6 \pm 4$ \\
\hline NDA & $0.15 \pm 0.10$ & $0.26 \pm 0.04$ & $0.03 \pm 0.01$ & $10.93 \pm 3.62$ & $0.24 \pm 0.16$ & $0.57 \pm 0.08$ & $0.82 \pm 0.02$ & $13.0 \pm 4$ \\
\hline
\end{tabular}

Table 3b: Concentrations of the 7 PAHs in the soils ( $\mu \mathrm{g} \mathrm{g}^{-1} \pm \mathrm{SD}$ ) at each site during the winter of 2014 .

\begin{tabular}{|c|c|c|c|c|c|c|c|c|}
\hline \multirow{2}{*}{ Sites } & \multicolumn{5}{|l|}{ LMW-PAHs } & \multicolumn{2}{|l|}{ HMW-PAHs } & \multirow[b]{2}{*}{$\Sigma_{7}[\mathrm{PAH}]$} \\
\hline & NA & $\mathrm{ACY}$ & FLUO & PHEN & ANTH & PYR & CHRY & \\
\hline $\mathrm{HD}$ & - & - & - & - & - & - & - & - \\
\hline $\mathrm{CD}$ & $0.25 \pm 0.01$ & $3.52 \pm 0.21$ & $1.66 \pm 0.12$ & $11.86 \pm 1.86$ & $3.91 \pm 0.55$ & $12.84 \pm 1.42$ & $1.89 \pm 0.04$ & $35.9 \pm 4.2$ \\
\hline DuTV & $0.23 \pm 0.03$ & $1.42 \pm 0.33$ & $2.97 \pm 0.03$ & $8.40 \pm 0.04$ & $3.27 \pm 0.06$ & $8.23 \pm 0.08$ & $1.58 \pm 0.66$ & $26.1 \pm 1.2$ \\
\hline AA & $0.18 \pm 0.05$ & $2.98 \pm 0.84$ & $2.30 \pm 0.11$ & $42.17 \pm 5.04$ & $4.28 \pm 0.37$ & $13.78 \pm 1.48$ & $7.02 \pm 1.18$ & $72.7 \pm 9$ \\
\hline
\end{tabular}




\begin{tabular}{|l|l|l|l|l|l|l|l|l|}
\hline MT & $0.22 \pm 0.09$ & $2.94 \pm 0.65$ & $3.78 \pm 1.63$ & $9.79 \pm 1.23$ & $15.25 \pm 2.97$ & $28.27 \pm 1.64$ & $3.33 \pm 1.42$ & $63.7 \pm 10$ \\
\hline JUM & $0.25 \pm 0.01$ & $2.16 \pm 0.03$ & $2.52 \pm 0.17$ & $14.08 \pm 3.77$ & $7.07 \pm 0.03$ & $10.27 \pm 2.09$ & $0.91 \pm 0.60$ & $37.3 \pm 7$ \\
\hline NDA & $0.21 \pm 0.05$ & $1.38 \pm 0.31$ & $0.59 \pm 0.40$ & $2.62 \pm 0.86$ & $1.34 \pm 0.89$ & $1.58 \pm 0.41$ & $4.42 \pm 0.24$ & $12.2 \pm 3$ \\
\hline
\end{tabular}

Table 3c: Concentrations of the 7 PAHs in the soils $\left(\mu \mathrm{g} \mathrm{g}^{-1} \pm \mathrm{SD}\right.$ ) at each site during the summer of 2015 (no soil samples were taken from the HD site during the summer season of 2015. The site was inaccessible).

\begin{tabular}{|c|c|c|c|c|c|c|c|c|}
\hline \multirow[b]{2}{*}{ Sites } & \multicolumn{5}{|l|}{ LMW-PAHs } & \multicolumn{2}{|l|}{ HMW-PAHS } & \multirow[b]{2}{*}{$\Sigma_{7}[\mathrm{PAH}]$} \\
\hline & NA & $\mathrm{ACY}$ & FLUO & PHEN & ANTH & PYR & CHRY & \\
\hline$H D$ & - & - & - & - & - & - & - & - \\
\hline$C D$ & $0.52 \pm 0.11$ & $1.49 \pm 0.20$ & $5.26 \pm 3.66$ & $25.66 \pm 3.47$ & $15.75 \pm 3.02$ & $68.55 \pm 8.94$ & $33.67 \pm 3.6$ & $150.9 \pm 29$ \\
\hline DuTV & $0.72 \pm 0.09$ & $5.58 \pm 0.96$ & $11.22 \pm 2.18$ & $197.10 \pm 20.75$ & $8.51 \pm 1.21$ & $32.46 \pm 1.92$ & $1.16 \pm 0.30$ & $256.8 \pm 27$ \\
\hline AA & $0.37 \pm 0.01$ & $1.56 \pm 0.32$ & $0.03 \pm 0.01$ & $1.08 \pm 0.72$ & ND & $9.16 \pm 0.15$ & $0.24 \pm 0.02$ & $12.4 \pm 1$ \\
\hline MT & $0.11 \pm 0.04$ & $0.78 \pm 0.47$ & $3.03 \pm 0.21$ & $2.64 \pm 0.94$ & $17.68 \pm 4.85$ & $13.60 \pm 3.35$ & $7.84 \pm 2.98$ & $45.7 \pm 13$ \\
\hline JUM & $1.57 \pm 0.18$ & $9.90 \pm 2.07$ & $3.41 \pm 0.36$ & $10.21 \pm 0.57$ & ND & $14.14 \pm 0.92$ & $0.70 \pm 0.62$ & $39.9 \pm 4.7$ \\
\hline NDA & $0.45 \pm 0.01$ & $3.12 \pm 1.07$ & $0.91 \pm 0.60$ & $3.09 \pm 2.25$ & $5.08 \pm 0.14$ & $15.58 \pm 0.13$ & $0.38 \pm 0.17$ & $28.6 \pm 4$ \\
\hline
\end{tabular}

Table 3d: Concentrations of the 7 PAHs in the soils ( $\mu \mathrm{g} \mathrm{g}^{-1} \pm \mathrm{SD}$ ) at each site during the spring of 2015 (no soil samples were taken from the HD site during the spring season of 2015 . The site was inaccessible).

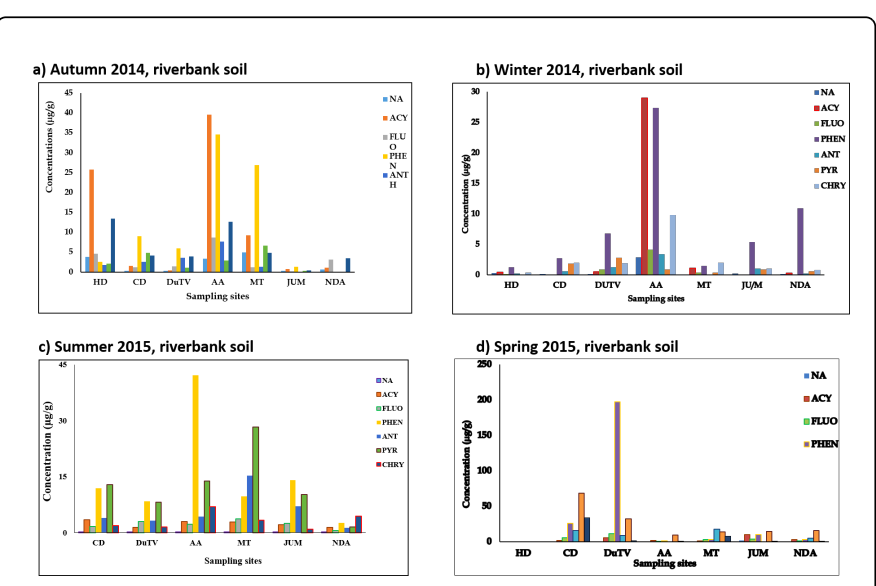

Figure 3: a-d) Seasonal distribution (autumn and winter of 2014; summer and spring of 2015) of the selected PAHs in the riverbank soils from sites along the Msunduzi River.

All the seven PAHs were positively identified in soils collected along the banks of the Msunduzi River. The $\Sigma_{7}[\mathrm{PAH}]$ ranged between $3.2 \mu \mathrm{g}$ $\mathrm{g}^{-1}$ (at JUM, autumn 2014) to $256.8 \mu \mathrm{g} \mathrm{g}^{-1}$ (at DuTV, summer 2015). The $\Sigma_{7}[\mathrm{PAH}]$ is significantly higher (at ppm $(\mathrm{w} / \mathrm{w})$ range) than in the river water (at $\mathrm{ppb}$ range $\mathrm{w} / \mathrm{v}$ ) at all sites along the river during the study, signifying the importance of river bank soil as a contributor matrix of PAHs into the water of the Msunduzi River.

As observed for the water samples, no seasonal variation could be correlated to the incidence of PAHs or to their pro ile distribution. As shown in Tables 3a-3d and Figure 3a-3d, soils collected at AA (a site close to a predominantly agrarian area) as well as MT (closer to an agrarian town) had consistently higher $\Sigma_{7}[\mathrm{PAH}]$ levels compared to the other sites. The two sites are both located downstream of the Darvill sewage treatment plant along the river basin. Increased concentration level at these sites may be due to stabilisation of PAHs through adsorption onto the clay-rich soils at these two sites. Incidentally, high $\Sigma_{7}[\mathrm{PAH}]$ levels were also measured for CD $(150.9 \mu \mathrm{g}$ $\mathrm{g}^{-1}$ and DuTV $\left(256.8 \mu \mathrm{g} \mathrm{g}^{-1}\right)$ during the spring of 2015. As already pointed for the water samples, the soil at the two sites is prone to PAHs contamination possibly from urban waste inputs. DuTV Bridge is very close to the N3 Freeway and experiences large volumes of traffic, which may introduce elevated amounts of PAHs from automobile exhaust fumes. $\mathrm{CD}$ is closer to an Aluminium refinery where coke production is done. Water runoff and illegal dumping are two other main conveyors of PAHs contamination of soils at this site.

Few studies on PAHs have been done on urban soils in South Africa $[19,21,34]$. The $\Sigma_{15}[\mathrm{PAH}]$ in soils sampled near three thermal power plants, Mpumalanga Province ranged between 9.73 and $61.24 \mu \mathrm{g} \mathrm{g}^{-1}$ dry weight [34] and are lower than the highest range reported here for spring, 2014, but comparable to that measured in winter 2014 or summer, 2015. The $\Sigma_{16}[\mathrm{PAH}]$ in the soils sampled from residential, agricultural and industrial areas along the Vaal Triangle River, Gauteng Province ranged between 0.04 and $39 \mu \mathrm{g} \mathrm{g}^{-1}$ dry weight [19] and are much lower than the results of this study. The same can be said about the $\Sigma_{16}[\mathrm{PAH}]$ reported in urban soils from Durban's eThekwini Municipality, KZN. The reported concentration range of 0.006 to 3.23 $\mu \mathrm{g} \mathrm{g}^{-1}$ dry weight [21] is lower compared to the overall range recorded in the present study. The mean concentrations observed particularly during the 2015 spring season is higher than that reported for urban roadway soils $\left(3780 \mu \mathrm{g} \mathrm{kg}^{-1}\right)$ collected from Shanghai in China [35] and in soils from kindergartens and playgrounds $\left(2,065 \mu \mathrm{g} \mathrm{kg}^{-1}\right.$ for $\left.\Sigma_{16}[\mathrm{PAH}]\right)$ in Bratislava, Slovakia [36]. 
Citation: Munyengabe A, Mambanda A, Moodley B (2017) Polycyclic Aromatic Hydrocarbons in Water, Soils and Surface Sediments of the Msunduzi River. J Environ Anal Chem 4: 227. doi:10.4172/2380-2391.1000227

Page 9 of 13

\section{Concentrations of PAHs in the surface sediments from the Msunduzi River}

The concentration levels of the 7 investigated PAHs in the surface sediments collected from the Msunduzi River basin and NDA during the autumn, winter seasons of 2014 and the summer spring seasons of 2015 are presented in Tables 4a-4d and graphed in Figure 4a-4d.

\begin{tabular}{|c|c|c|c|c|c|c|c|c|}
\hline \multirow[b]{2}{*}{ Sites } & \multicolumn{5}{|l|}{ LMW-PAHs } & \multicolumn{2}{|l|}{ HMW-PAHs } & \multirow[b]{2}{*}{$\Sigma_{7}[\mathrm{PAH}]$} \\
\hline & NA & ACY & FLUO & PHEN & ANTH & PYR & CHRY & \\
\hline HD & $0.16 \pm 0.14$ & $0.67 \pm 0.50$ & $0.50 \pm 0.04$ & $0.69 \pm 0.24$ & ND & ND & $0.11 \pm 0.05$ & $2.15 \pm 0.97$ \\
\hline$C D$ & $1.27 \pm 0.36$ & $1.56 \pm 0.62$ & $0.22 \pm 0.20$ & $1.45 \pm 0.13$ & $0.24 \pm 0.08$ & $0.07 \pm 0.03$ & $0.57 \pm 0.54$ & $5.39 \pm 1.96$ \\
\hline DuTV & $0.16 \pm 0.01$ & $0.16 \pm 0.06$ & $0.20 \pm 0.10$ & $0.24 \pm 0.09$ & $1.06 \pm 0.53$ & ND & $0.13 \pm 0.02$ & $1.96 \pm 0.81$ \\
\hline AA & $4.51 \pm 1.84$ & $50.21 \pm 11.66$ & $11.85 \pm 3.86$ & $42.92 \pm 11.06$ & $12.70 \pm 8.52$ & $6.31 \pm 1.44$ & $17.65 \pm 5.03$ & $146.16 \pm 43.41$ \\
\hline MT & $0.25 \pm 0.20$ & $0.32 \pm 0.05$ & $1.18 \pm 0.29$ & $1.37 \pm 1.21$ & $0.87 \pm 0.24$ & $0.73 \pm 0.08$ & $0.41 \pm 0.02$ & $5.15 \pm 2.09$ \\
\hline JUM & $0.25 \pm 0.21$ & ND & ND & $1.64 \pm 1.02$ & $0.19 \pm 0.02$ & ND & ND & $2.09 \pm 1.25$ \\
\hline NDA & $0.24 \pm 0.10$ & $0.17 \pm 0.02$ & $0.30 \pm 0.14$ & ND & ND & ND & $0.36 \pm 0.25$ & $1.09 \pm 0.51$ \\
\hline
\end{tabular}

Table 4a: Concentrations of the 7 PAHs in the surface sediments $\left(\mu \mathrm{g} \mathrm{g}^{-1} \pm \mathrm{SD}\right)$ at each site during the autumn of 2014 .

\begin{tabular}{|c|c|c|c|c|c|c|c|c|}
\hline \multirow[b]{2}{*}{ Sites } & \multicolumn{5}{|l|}{ LMW-PAHs } & \multicolumn{2}{|l|}{ HMW-PAHs } & \multirow[b]{2}{*}{$\Sigma_{7}[\mathrm{PAH}]$} \\
\hline & NA & ACY & FLUO & PHEN & ANTH & PYR & CHRY & \\
\hline $\mathrm{HD}$ & $0.02 \pm 0.01$ & $0.09 \pm 0.25$ & $1.68 \pm 0.63$ & $1.10 \pm 0.57$ & ND & $0.98 \pm 0.08$ & $0.43 \pm 0.26$ & $4.32 \pm 1.80$ \\
\hline$C D$ & $0.09 \pm 0.04$ & $0.18 \pm 0.02$ & $0.63 \pm 0.08$ & $7.39 \pm 3.90$ & $1.59 \pm 0.13$ & $0.93 \pm 0.04$ & $1.67 \pm 0.98$ & $12.52 \pm 5.19$ \\
\hline DuTV & $0.12 \pm 0.06$ & ND & ND & $3.15 \pm 0.19$ & $4.44 \pm 0.45$ & $1.60 \pm 0.66$ & $1.10 \pm 0.11$ & $10.42 \pm 1.47$ \\
\hline AA & $0.18 \pm 0.05$ & $0.40 \pm 0.28$ & $2.15 \pm 0.70$ & $2.49 \pm 0.32$ & $1.04 \pm 0.38$ & $0.11 \pm 0.05$ & $7.17 \pm 2.18$ & $13.58 \pm 3.96$ \\
\hline MT & $0.02 \pm 0.01$ & $0.02 \pm 0.02$ & $0.30 \pm 0.69$ & $1.65 \pm 0.67$ & $0.19 \pm 0.03$ & $0.91 \pm 0.35$ & $0.62 \pm 0.33$ & $3.73 \pm 2.10$ \\
\hline JUM & $0.04 \pm 0.01$ & ND & $0.35 \pm 0.11$ & $2.83 \pm 0.84$ & $0.92 \pm 0.24$ & $1.43 \pm 0.57$ & $2.55 \pm 0.63$ & $8.65 \pm 2.40$ \\
\hline NDA & $0.25 \pm 0.20$ & $0.02 \pm 0.01$ & $0.165 \pm 0.09$ & $6.26 \pm 1.68$ & $0.83 \pm 0.70$ & ND & $0.53 \pm 0.41$ & $8.07 \pm 3.09$ \\
\hline
\end{tabular}

Table 4b: Concentrations of the 7 PAHs in the surface sediments ( $\mu \mathrm{g} \mathrm{g}^{-1} \pm \mathrm{SD}$ ) at each site during the winter of 2014 .

\begin{tabular}{|c|c|c|c|c|c|c|c|c|}
\hline \multirow[b]{2}{*}{ Sites } & \multicolumn{5}{|l|}{ LMW-PAHs } & \multicolumn{2}{|l|}{ HMW-PAHs } & \multirow[b]{2}{*}{$\sum_{7}[\mathrm{PAH}]$} \\
\hline & NA & $\mathrm{ACY}$ & FLUO & PHEN & ANTH & PYR & CHRY & \\
\hline HD & - & - & - & - & - & - & - & - \\
\hline$C D$ & $1.48 \pm 0.02$ & $0.23 \pm 0.50$ & $3.74 \pm 0.32$ & $8.17 \pm 1.88$ & $2.96 \pm 0.88$ & $8.22 \pm 3.69$ & $0.93 \pm 0.47$ & $25.70 \pm 7.76$ \\
\hline DuTV & $1.24 \pm 0.08$ & $0.19 \pm 0.06$ & $1.59 \pm 0.82$ & $4.53 \pm 1.11$ & $0.51 \pm 0.33$ & $1.01 \pm 0.77$ & $0.36 \pm 0.02$ & $9.46 \pm 3.19$ \\
\hline AA & $0.16 \pm 0.09$ & $1.67 \pm 0.49$ & $4.76 \pm 2.37$ & $6.86 \pm 0.39$ & $4.77 \pm 1.96$ & $6.53 \pm 2.61$ & $1.42 \pm 0.80$ & $26.20 \pm 8.71$ \\
\hline MT & $0.61 \pm 0.01$ & $0.25 \pm 0.46$ & $1.15 \pm 0.07$ & $5.35 \pm 0.56$ & $2.40 \pm 1.53$ & $8.27 \pm 1.88$ & $0.63 \pm 0.43$ & $18.68 \pm 4.94$ \\
\hline JUM & $0.09 \pm 0.03$ & $2.55 \pm 0.33$ & $6.12 \pm 0.65$ & $6.59 \pm 0.48$ & $7.27 \pm 1.45$ & $32.19 \pm 6.69$ & $0.88 \pm 0.37$ & $55.71 \pm 10.00$ \\
\hline NDA & $0.27 \pm 0.01$ & $2.74 \pm 0.02$ & $0.78 \pm 0.11$ & $20.95 \pm 0.04$ & $8.26 \pm 0.01$ & $10.91 \pm 1.47$ & $2.49 \pm 0.01$ & $46.43 \pm 1.67$ \\
\hline
\end{tabular}

Table 4c: Concentrations of the 7 PAHs in the surface sediments ( $\mu \mathrm{g} \mathrm{g}^{-1} \pm \mathrm{SD}$ ) at each site during the summer of 2015 (no surface sediment samples were collected from the HD site during the summer season of 2015. This site was inaccessible). 


\begin{tabular}{|c|c|c|c|c|c|c|c|c|}
\hline \multirow[b]{2}{*}{ Sites } & \multicolumn{5}{|l|}{ LMW-PAHs } & \multicolumn{2}{|l|}{ HMW-PAHs } & \multirow[b]{2}{*}{$\Sigma_{7}[\mathrm{PAH}]$} \\
\hline & NA & ACY & FLUO & PHEN & ANTH & PYR & CHRY & \\
\hline HD & - & - & - & - & - & - & - & - \\
\hline$C D$ & $0.27 \pm 0.15$ & $3.60 \pm 2.05$ & $2.18 \pm 1.27$ & $23.60 \pm 2.57$ & $0.72 \pm 0.08$ & $36.23 \pm 5.92$ & $1.82 \pm 0.73$ & $68.42 \pm 12.77$ \\
\hline DuTV & $1.12 \pm 0.33$ & $11.86 \pm 2.46$ & $3.26 \pm 1.84$ & $16.71 \pm 9.95$ & $23.98 \pm 5.25$ & $69.07 \pm 14.26$ & $4.92 \pm 0.59$ & $130.92 \pm 34.68$ \\
\hline AA & $0.86 \pm 0.07$ & $67.33 \pm 8.17$ & $3.34 \pm 0.97$ & $8.31 \pm 0.18$ & $41.13 \pm 0.62$ & $37.65 \pm 0.20$ & $1.43 \pm 0.72$ & $160.05 \pm 10.93$ \\
\hline MT & $0.85 \pm 0.06$ & $2.86 \pm 0.34$ & $1.18 \pm 0.29$ & $2.12 \pm 1.19$ & $1.87 \pm 0.29$ & $4.62 \pm 0.41$ & ND & $13.50 \pm 2.58$ \\
\hline JUM & $2.65 \pm 0.39$ & $16.28 \pm 3.03$ & $41.72 \pm 8.94$ & $39.92 \pm 5.78$ & $6.67 \pm 0.76$ & $6.57 \pm 1.98$ & $1.60 \pm 0.02$ & $115.41 \pm 20.90$ \\
\hline NDA & $0.46 \pm 0.06$ & $3.77 \pm 0.02$ & $0.83 \pm 0.76$ & $2.59 \pm 0.33$ & $15.75 \pm 0.14$ & $17.94 \pm 9.93$ & $0.18 \pm 0.04$ & $41.52 \pm 11.28$ \\
\hline
\end{tabular}

Table 4d: Concentrations of the 7 PAHs in the surface sediments ( $\mu \mathrm{g} \mathrm{g}^{-1} \pm \mathrm{SD}$ ) at each site during the spring of 2015 (no surface sediment samples were taken from the HD site during the spring season of 2015. The site was inaccessible).

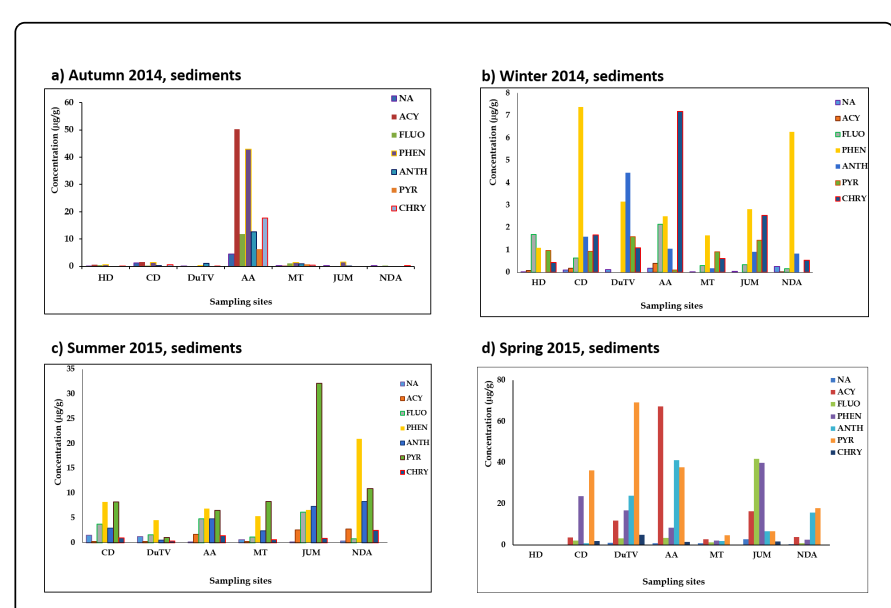

Figure 4: a-d) Seasonal distribution (autumn and winter of 2014; summer and spring of 2015) of the selected PAHs in the river sediments from sites along the Msunduzi River.

As, already reported for water and soils, there was no discernible distribution pattern of the selected PAHs at each site nor was there a clear trend in concentration levels along the river basin.

The $\Sigma_{7}[\mathrm{PAH}]$ in surface sediment ranged from 1.0 to $146.1 \mu \mathrm{g} \mathrm{g}^{-1}$ during the study period with the highest incidence of $\mathrm{PAH}$ contamination (contributed mainly by ACY, PHEN, ANTH AND CHRY) occurring at AA. In autumn of the same year, the range was 3.7-13.5 $\mu \mathrm{g} \mathrm{g}^{-1}$. In summer of 2015 , the concentration range was 9.4-55.7 $\mu \mathrm{g} \mathrm{g}^{-1}$. The highest concentration range of PAHs in sediments of 13.5-160.0 $\mathrm{ug} \mathrm{g}^{-1}$ was measured in spring of 2015. Notable during this season were the high levels of PAHs found in sediments from AA (contributed mainly by ACY $67.3 \mu \mathrm{g} \mathrm{g}^{-1}$, ANTH $41.1 \mu \mathrm{g} \mathrm{g}^{-1}$, PRY 37.6 $\mu \mathrm{g} \mathrm{g}^{-1}$ ) and DuTV (contributed mainly by PRY $69.1 \mu \mathrm{g} \mathrm{g}^{-1}$, ANTH 24.0 $\mu \mathrm{g} \mathrm{g}^{-1}$, ACY $16.7 \mu \mathrm{g} \mathrm{g}^{-1}$, PHEN $\left.11.9 \mu \mathrm{g} \mathrm{g}^{-1}\right)$. AA is located downstream of DWWTP, which discharges treated water effluent back into the river. Downstream sediments may be contaminated from residual PAHs due to cumulative deposition as fine particles. Controlled burning of old crop stalks or dry grass to clear land for planting crops as well as natural veld fires around AA are also important sources of
PAHs reaching the river sediments. Sediments at this site have high clay content. The PAHs-clay-sediment complexes which form are stable and persistent and thus resist biochemical conversion to other products or mobilization via water washing due to their low water solubility. On one hand, the high levels of PAHs at DuTV were attributed to fallouts from vehicle emissions as well as illegal dumping from the nearby shanty settlements and industries.

At each site along the Msunduzi River, the $\Sigma_{7}[\mathrm{PAH}]$ in surface sediments are markedly higher than the concentration ranges recorded for water samples. PAHs and other organic pollutants have a strong affinity to adsorb onto the organic or clay particles present in the sediments as well as the pore water due to their hydrophobicity (high $\log \left(\mathrm{K}_{\mathrm{ow}}\right)$ values). There are few reports on the incidence of PAHs on the surface sediments in South Africa $[21,26,28,30]$. Nekhavhambe et al. [28], reported a $\Sigma_{23}[\mathrm{PAH}]$ range of $0.11-344 \mu \mathrm{g} \mathrm{g}^{-1}$ in surface sediments while Das et al. [26] reported a $\Sigma_{23}[\mathrm{PAH}]$ average of $369 \mu \mathrm{g}$ $\mathrm{g}^{-1}$, both concentration values of which are higher than those reported in this study. In another study, the concentration levels of PAHs in the KZN river sediments was determined and found to be in the range of 0.006 to $3.24 \mu \mathrm{g} \mathrm{g}^{-1}$ [21]. The highest $\Sigma_{7}[\mathrm{PAH}]$ range measured in Msunduzi sediments (spring of 2015) is lower than the $\Sigma_{16}[\mathrm{PAH}]$ (362 to $15,667 \mathrm{ng} \mathrm{g}^{-1}$ ) found in the surface sediments collected from the Weihe River in China [37] and sediments collected from the Tianjin River in China (0.79-194.30 $\left.\mu \mathrm{g} \mathrm{g}^{-1}\right)$ [38] but higher than that observed in the surface sediments $\left(0.0016-0.97 \mathrm{mg} \mathrm{kg}^{-1}\right.$ from Ekpan Creek of the Warri River, Niger Delta region [39]. In rivers from regions with a similar climatic conditions, surface sediments have been found to be widely contaminated from PAHs emissions from the catchment area of the river as found in this study $[40,41]$.

Seasonal Variations of PAH Concentration and Physical Parameters of the Water PAHs can undergo different chemical reactions and volatilization from the aquatic system into the atmosphere depending on the season. In South Africa seasonal changes are dramatic during the summer and spring seasons. Temperature and rainfall are normally high contributing to volatilization and dilution effects. This in turn changes the steady-state concentration of PAHs in water, soils, and surface sediments. The range of $\Sigma_{7}[\mathrm{PAH}]$ in water for all seasons decreased in the order: $\Sigma_{7}[\mathrm{PAH}]$ spring $>\Sigma_{7}[\mathrm{PAH}]$ summer $>\Sigma_{7}[\mathrm{PAH}]$ autumn $>\Sigma_{7}[\mathrm{PAH}]$ winter, while in the surface sediments it was in the order: 
$\Sigma_{7}[\mathrm{PAH}]$ spring $>\Sigma_{7}[\mathrm{PAH}]$ autumn $>\Sigma_{7}[\mathrm{PAH}]$ summer $>\Sigma_{7}[\mathrm{PAH}]$ winter and in the soils were in the order:

$\Sigma_{7}[\mathrm{PAH}]$ spring $>\Sigma_{7}[\mathrm{PAH}]$ autumn $>\Sigma_{7}[\mathrm{PAH}]$ winter $>\Sigma_{7}$

$[\mathrm{PAH}]$ summer.

Normally, the seasonal variation of the concentrations of PAHs in soils and surface sediments should follow the same order. The $\Sigma_{7}[\mathrm{PAH}]$ in the surface sediments during the summer season of 2015 was high but lower than in soils sampled in winter 2014. This could be due to the heavy rainfall occurring during the summer season, which can wash PAHs from surface soils and accumulate them in the aquatic sediments, resulting in higher concentrations of PAHs in surface sediments than in soils [2].

The winter seasons in KZN Province is accompanied by strong and cold winds, and occasional frosts in some areas stretching upto the Midlands region of PMB. Spring seasons receive slight rainfall and experience warmer weather. Domestic heating and occasionally land clearance by regulated burning reached their peaks during this time resulting in elevated emissions and fallout of PAHs into the atmosphere and receiving aquatic environments.

\section{Source apportionment of PAHs found in the Msunduzi River basin}

Sources of PAHs in the environment can be classified as either petrogenic (petroleum derived) or pyrogenic (combustion in limited oxygen). In general, petrogenic sources emit significant amounts of LMW-PAHs (those of 2 or 3 rings) while pyrogenic of organic derived biomass emit PAHs with significant amounts of 4-6 rings [9]. In this study, the isomeric concentration ratio $\{[$ Anth $] /([$ Anth $]+[$ Phen $])\}$ was used to characterize the origins of PAHs along the Msunduzi River basin [41-43]. The results are summarized in Table 5.

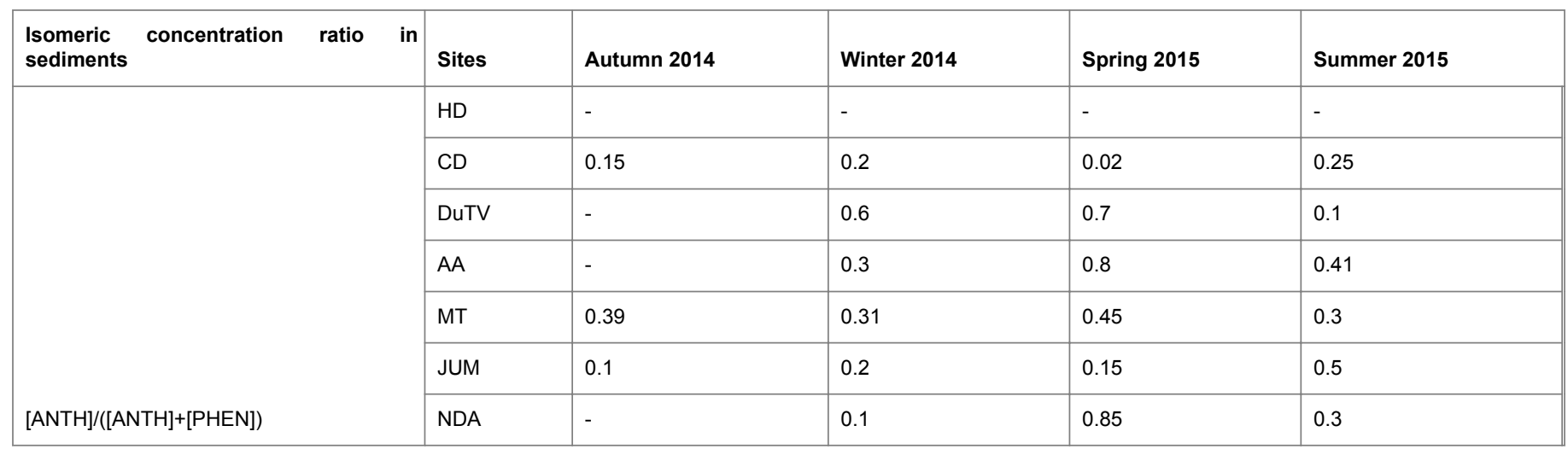

Table 5: Calculated isomeric $\{[$ Anth $] /([$ Anth $]+[$ Phen $])\}$ ratios for sediments and probable source of PAHs in the Msunduzi River.

Petrogenic sources: if $[$ ANTH $] /([$ ANTH $]+[$ PHEN $])<0.1$; Pyrogenic sources: if $[\mathrm{ANTH}] /([\mathrm{ANTH}]+[\mathrm{PHEN}])>0.1$.

Since sediments are considered the main matrix destination for PAHs contamination in the aquatics environment, their data was used for source apportionment. About $80 \%$ of the sediments along the river basin had an isomeric ratio, [Anth]/([Anth]+[Phen]) greater than 0.1 (Table 5). This is a good indication that the PAHs in the sediments are derived from pyrolytic sources rather than from leakage of petroleum derived fuels and lubricants from urban off. Similar source apportionments were reported for mangrove sediments, North Persian Gulf [44] and open-pit sediments from a mining area at Cerro de Pasco, Andes [45].

As already pointed out, important sources around the most contaminated section of river basin (sites near PMB) include vehicle fumes, burning at undesignated dumpsites, domestic burning and illegal dumping of wastes.

\section{Conclusions}

Water, riverbank soils and surface sediments from Msunduzi River in KZN Province were found to be contaminated with trace levels of PAHs. Surface sediments had elevated concentration levels of PAH compared to the column of water above them. The concentration levels as well as the distribution of the selected PAHs varied from season to season, however with no clear pattern. The occurrence pattern of PAHs along the river points to human-related activities as the major input sources of PAHs into Msunduzi water.

Isomeric concentration ratios for surface sediments suggested pyrolysis as the major input source of PAHs, especially at sites closer to the city of PMB. Possible sources of PAHs around PMB include vehicular emissions (incomplete burning of gasoline, diesel fuel including oil leakage from car repair garages) domestic burning (of domestic wastes at undesignated dumping points, firewood and paraffin) and industrial emissions.

\section{Acknowledgement}

We acknowledge financial support from the University of KZN, South Africa. We also thank Mrs. C. Janse van Resenburg for her help in Mass Spectral Analysis.

\section{Competing interests}

We declare there are no unbearing financial influences or motives in the scientific arguments put across in this paper.

\section{Authors' contributions}

Field and Lab work were performed by A. Munyengabe while AM and BM supervised work as well as critiques the written draft manuscripts. 


\section{References}

1. Abdel-Shafy HI, Mansour MSM (2016) A review on polycyclic aromatic hydrocarbons: Source, environmental impact, effect on human health and remediation. Egyptian Journal of Petroleum 25: 107-123.

2. Zheng Y, Luo X, Zhang W, Wu B, Han F, et al. (2012) Enrichment behaviour and transport mechanism of soil-bound PAHs during rainfallrunoff events. Environ Pollut 171: 85-92.

3. Mastral AM, Callen MS (2000) A Review on Polycyclic Aromatic Hydrocarbons (PAH) Emissions from Energy Generation. Environ Sci Technol 34: 3051-3057.

4. Azhari A (2012) Polycyclic aromatic hydrocarbons (PAHs) in air and vegetation: A case study of three selected toll stations along North, South Expressway in Johor, Malaysia. Universiti Tun Hussein Onn, Malaysia.

5. Godefroy SJ, Martincigh BS, Salter LF (2005) Measurements of Polycyclic Aromatic Hydrocarbons and Genotoxicity in Soot Deposited at a Toll Plaza near Durban, South Africa. S Afr J Chem 58: 61-66.

6. Agency for Toxic Substances and Disease Registry (ATSDR) (2001) Public Health Statement, Polycyclic Aromatic Hydrocarbons. Atlanta, GA: USA Department of Health and Human Service.

7. Laflamme RE, Hites RA (1978) The global distribution of polycyclic aromatic hydrocarbons in recent sediments. Geochim Cosmochim Acta 42: 289-303.

8. Qiao M, Wang C, Huang S, Wang D, Wang Z (2006) Composition, sources, and potential toxicological significance of PAHs in the surface sediments of the Meiliang Bay, Taihu Lake, China. Environ Int 32: 28-33.

9. Fernández P, Vilanova RM, Martínez C, Appleby P, Grimalt JO (2000) The Historical Record Of Atmospheric Pyrolytic Pollution Over Europe Registered In The Sedimentary PAH From Remote Mountain Lakes. Environ Sci Technol 34: 1906-1913.

10. Sakari M (2012) Depositional history of Polycyclic Aromatic Hydrocarbons: Reconstruction of Petroleum Pollution Record in Peninsular Malaysia. In: Puzyn T, Mostrag-Szlichtyng A (eds.) Organic Pollutants Ten Years After the Stockholm Convention-Environmental and Analytical Update. INTECH.

11. Becker S, Halsall CJ, Tych W, Hung H, Attewell S, et al. (2006) Resolving The Long-Term Trends Of Polycyclic Aromatic Hydrocarbons In The Canadian Arctic Atmosphere. Environ Sci Technol 40: 3217-3222.

12. Rose NL, Rose CL, Boyle JF, Appleby PG (2004) Lake-Sediment Evidence for Local and Remote Sources of Atmospherically Deposited Pollutants on Svalbard. J Paleolimnol 31: 499-513.

13. Harvey RG (1982) Polycyclic Hydrocarbons and Cancer: Certain common environmental pollutants are converted by mammalian cells into metabolites that can induce cancer through their reactions with cellular nucleic acids. Am Scientist. 70: 386-393.

14. Ramesh A, Archibong AE, Hood DB, Guo Z, Loganathan BG (2011) Global Environmental distribution and human health effects of polycyclic aromatic hydrocarbons. In: Loganathan BG, Lam PKS (eds.) Global contamination trends of persistent organic chemicals. Boca Raton Florida: CRC Press, pp. 95-124.

15. Masih A, Taneja A (2006) Polycyclic Aromatic Hydrocarbons (PAHs) concentrations and related carcinogenic potencies in soil at a semi-arid region of India. Chemosphere 65: 449-456.

16. Baird WM, Hooven LA, Mahadevan B (2005) Carcinogenic polycyclic aromatic hydrocarbon-DNA adducts and mechanism of action. Environ Mol Mutagen 45: 106-114.

17. WHO Regional Office for Europe. In (WHO Regional Office for Europe). Air Quality Guidelines: PAHs, 2nd ed, Denmark: WHO Regional Office for Europe; 2000:Ch. 5.9.

18. Meador JP, Casillas E, Sloan CA, Varanasi U (1995) Comparative bioaccumulation of polycyclic aromatic hydrocarbons from sediment by two in faunal invertebrates. Mar Ecol Prog Ser 123: 107-124.

19. Nieuwoudt C, Pieters R, Quinn LP, Kylin H, Borgen AR (2011) Polycyclic Aromatic Hydrocarbons (PAHS) in Soil and Sediment from Industrial,
Residential, and Agricultural Areas in Central South Africa: An Initial Assessment. Soil Sediment Contam 20: 188-204.

20. Chimuka L, Sibiya P, Amdany R, Cukrowska E, Forbes PBC (2016) Status Of PAHS In Environmental Compartments of South Africa: A Country Report. Polycyclic Aromat Compd 36: 376-394.

21. Vogt NL (2014) Quantification of PAHs and PCBs in the eThekwini aquatic systems using chemical and biological analysis. University of North-West, South Africa.

22. Cele IS (2010) Determination of inorganic and polynuclear aromatic hydrocarbon contents in South African sewage sludge. University of KwaZulu-Natal, South Africa.

23. Gemmell ME, Schmidt S (2013) Is the microbiological quality of the Msunduzi River (KwaZulu-Natal, South Africa) suitable for domestic, recreational, and agricultural purposes? Environ Sci Pollut Res 20: 6551-6562.

24. USA-Environmental Protection Agency (US EPA). Separator Funnel Liquid-liquid Extraction. EPA Method 3510-C. 40 CFR 136, 3rd Revision; Washington DC: USA Environmental Protection Agency; 1996b.

25. USA-Environmental Protection Agency (US EPA). Method 3540C: Soxhlet Extraction. Washington DC: USA Environmental Protection Agency; 1996c.

26. Das SK, Routh J, Roychoudhury AN (2008) Sources and historic changes in polycyclic aromatic hydrocarbon input in a shallow lake, Zeekoevlei, South Africa. Org Geochem 39: 1109-1112.

27. Sibiya PN (2012) Modification, development and application of extraction methods for PAHs in the water and sediments. University of the Witwatersrand, South Africa.

28. Nekhavhambe TJ, van Ree T, Fatoki OS (2014) Determination and distribution of polycyclic aromatic hydrocarbons in rivers, surface runoff, and sediments in and around Thohoyandou, Limpopo Province, South Africa. Water S Afr 40: 415-424.

29. Amdany R, Chimuka L, Cukrowska E, Kukucka P, Kohoutek J, et al. (2014) Investigating the temporal trends in PAH, PCB and OCP concentrations in Hartbeespoort Dam, South Africa, using Semipermeable Membrane Devices (SPMDs). Water S Afr 40: 425-436.

30. Edokpayi JN, Odiyo JO, Popoola OE, Msagati TAM (2016) Determination and Distribution of Polycyclic Aromatic Hydrocarbons in Rivers, Sediments and Wastewater Effluents in Vhembe District, South Africa. Int J Environ Res Public Health 13: 387-399.

31. Santana JL, Massone CG, Valdés M, Vazquez R, Lima LA, et al. (2015) Occurrence and Source Appraisal of Polycyclic Aromatic Hydrocarbons (PAHs) in Surface Waters of the Almendares River, Cuba. Arch Environ Contam Toxicol 69: 143-152.

32. Guo W, He M, Yang Z, Lin C, Quan X, et al. (2007) Distribution of polycyclic aromatic hydrocarbons in water, suspended particulate matter and sediment from Daliao River watershed, China. Chemosphere 68: 93-104.

33. Guo W, He M, Yang Z, Lin C, Quan X, et al. (2009) Distribution, partitioning and sources of polycyclic aromatic hydrocarbons in the Daliao river water system in dry season, China. J Haz Mat 164: 1379-1385.

34. Okedeyi OO, Nindi MM, Dube S, Awofolu OR (2013) Distribution and potential sources of polycyclic aromatic hydrocarbons in soils around coal-fired power plants in South Africa. Environ Monit Assess 185: 2073-2082.

35. Jiang YF, Wang T, Wang F, Jia Y, Wu MH, et al. (2009) Levels, composition profiles and sources of polycyclic aromatic hydrocarbons in urban soil of Shanghai, China. Chemosphere 75: 1112-1118.

36. Hiller E, Lachká L, Jurković L, Vozár, J (2015) Polycyclic aromatic hydrocarbons in urban soils from kindergartens and playgrounds in Bratislava, the capital city of Slovakia. Environ Earth Sci 73: 7147-7156.

37. Chen Y, Jia R, Yang S (2015) Distribution and Source of Polycyclic Aromatic Hydrocarbons(PAHs) in Water Dissolved Phase, Suspended Particulate Matter and Sediment from Weihe River in Northwest China. Int J Environ Res Public Health 12: 14148-14163. 
Citation: Munyengabe A, Mambanda A, Moodley B (2017) Polycyclic Aromatic Hydrocarbons in Water, Soils and Surface Sediments of the Msunduzi River. J Environ Anal Chem 4: 227. doi:10.4172/2380-2391.1000227

Page 13 of 13

38. Shi Z, Tao S, Pan B, Fan W, He XC, et al. (2005) Contamination of rivers in Tianjin, China by polycyclic aromatic hydrocarbons. Environ Pollut 134: $97-111$.

39. Duke OF (2008) Source determination of polynuclear aromatic hydrocarbons in water and sediment of a creek in the Niger Delta region. Afr J Biotechnol 7: 282-285.

40. Malik A, Verma P, Singh AK, Singh KP (2011) Distribution of polycyclic aromatic hydrocarbons in water and bed sediments of the Gomti River, India. Environ Monit Assess 172: 529-545.

41. Dong CD, Chen CF, Chen CW (2012) Determination of Polycyclic Aromatic Hydrocarbons in Industrial Harbor Sediments by GC-MS. Int J Environ Res Public Health 9: 2175-2188.

42. Soclo H, Garrigues P, Ewald M (2000) Origins of Polycyclic Aromatic Hydrocarbons (PAHs) in Coastal Marine Sediments: Case Studies in Cotonou (Benin) and Aquitaine (France) Areas. Mar Pollut Bull 40: 387-396.
43. Zhang L, Dong L, Ren L, Shi S, Zhou L, et al. (2012) Concentration and source identification of polycyclic aromatic hydrocarbons and phthalic acid esters in the surface water of the Yangtze River Delta, China. J Environ Sci 24: 335-342.

44. Mohebbi-Nozar SL, Zakaria MP, Mortazavi MS, Ismail WR, Jokar KK (2016) Concentrations and Source Identification of Polycyclic Aromatic Hydrocarbons (PAHs) in Mangrove Sediments from North of Persian Gulf Polycyclic Aromatic Compounds. Polycyclic Aromat Compd 36: 601-612.

45. Orecchio S, Bianchini F, Bonsignore R, Blandino P, Barreca S, Amorello D (2016) Profiles and Sources of PAHs in Sediments from an Open-Pit Mining Area in the Peruvian Andes. Polycyclic Aromat Compd 36: 429-451. 